\title{
Performance, body nitrogen conversion and nitrogen emission from manure of dairy cows fed diets supplemented with different plant extracts
}

\author{
B.J. Śliwiński, M. Kreuzer ${ }^{1}$, F. Sutter ${ }^{2}$, A. Machmüller ${ }^{3}$ and \\ H.-R. Wettstein
}

\author{
Institute of Animal Sciences, Animal Nutrition, \\ Swiss Federal Institute of Technology (ETH) Zurich, ETH Centre/LFW \\ CH-8092 Zurich, Switzerland
}

(Received 14 January 2003; revised version 13 October 2003; accepted 14 January 2004)

\begin{abstract}
In two experiments with lactating cows the effect of supplemented small doses of essential oils ( $0.1 \mathrm{~g}$ extract $/ \mathrm{kg}$; experiment I), Yucca schidigera saponin $(0.1 \mathrm{~g}$ extract $/ \mathrm{kg})$ or Castanea sativa wood tannin ( $4.9 \mathrm{~g}$ extract $/ \mathrm{kg}$ ) were compared with unsupplemented diets and a soyabean meal-supplemented diet (only experiment II). Performance (liveweight change, milk yield and composition) was not affected although, in order to provoke effects, diets were deficient in protein by $\leq 10 \%$. An exception was the soyabean meal-supplemented diet which also showed only non-significant trends towards higher persistencies of milk and milk protein synthesis. Effects of the extracts rich in saponins and tannins occurred in nitrogen conversion in the animal (less urinary and milk urea nitrogen excretion) and in manure. Nitrogen emissions from 8-weeks stored manure were lower relative to the unsupplemented diet. The main field of application of the extracts rich in tannins and saponins seems to be the mitigation of ammonia emission.
\end{abstract}

KEY WORDS: milk, protein, tannins, saponins, essential oils, urea

\section{INTRODUCTION}

Subsequent to the ban of either all or most antibiotics from feeding of livestock in many European countries, search for efficient feed additives has shifted towards na-

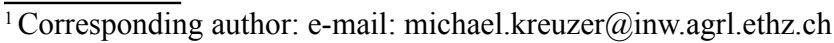

${ }^{2}$ Present address: Swiss Centre for Agricultural Extension (LBL), CH-8315 Lindau, Switzerland

${ }^{3}$ Preseent addres: School of Rural Science and Agriculture, University of New England, Armidale NSW 2351, Australia
} 
tural compounds, particularly secondary plant constituents. Examples are essential oils, saponins or tannins which are usually available as major compounds of certain plant extracts. Given at high levels, these substances may have adverse nutritional effects by reducing palatability, intake and digestibility of the diet and, in very high concentrations, they could even get toxic (Makkar, 1993; Klita et al., 1996). In turn, moderate or low quantities of these extracts may reduce the ruminal release of ammonia and, by this or other modes of action, may enhance the supply of 'by-pass' proteins to be digested in the small intestine. Effects of plant extracts containing Yucca schidigera saponin and Castanea sativa wood tannin on nitrogen $(\mathrm{N})$ conversion in the rumen and in the animal were recently reviewed and experimentally shown both in vitro and in growing sheep (Śliwiński et al., 2002a,b). For the essential oils, Hammer et al. (1999) noted in vitro that many types, and the corresponding plant extracts, have antibacterial and antifungal activity, with the consequence of a reduced ruminal ammonia release (Wallace et al., 2002). Dairy cow diets are often limited in metabolically available protein rather than in net energy. This may open an important field of application for plant extracts containing secondary plant constituents, either to prevent a protein deficiency thus improving performance or to reduce losses of non-utilized $\mathrm{N}$ from the animal and from manure in the form of environmentally hazardous ammonia emissions (Kröber et al., 2000). The latter effects are particularly expected from saponins and tannins, as saponins massively reduce ruminal ammonia formation (discussed in detail by Śliwiński et al., 2002b) and tannins are known to form complexes with protein (Brooker et al., 2002). This means that secondary plant constituents may also be interesting in improving $\mathrm{N}$ utilization and reducing environmental pollution in dairy husbandry as major elements of current animal nutrition strategies (Castillo et al., 2000).

The objective of the present study was, therefore, to investigate the effects of three commercially available products either rich in essential oils, saponins or tannins using diets with a calculated slight deficiency of metabolically available protein. These diets should supply net energy as recommended. Since the product rich in essential oils also contained herbs and spices which, according to the manufacturer's statement, should increase milk yield predominantly by a better feed palatability, feed allocation was set to quasi ad libitum supply. The occurrence of the assumed ammonia and urea-related effects of the extracts rich in saponins and tannins was tested by various traits of digestion, metabolism and excretion of $\mathrm{N}$ as well as a manure storage trial.

\section{MATERIAL AND METHODS}

\section{Experimental design}

Experiment I was designed as a cross-over arrangement including eight replicates of two treatments each. This dataset was obtained in two subsequent series 
with four cows per treatment sequence each. Prior to treatment feeding, the cows received a standard total mixed ration, and data from each cow was collected (defined here as week 0 ). During the following four weeks (Period 1 ) four animals were fed with a control diet and four cows with a supplemented diet. In week 5, treatments were exchanged, and this was followed by another measurement period of four weeks (Period 2, weeks 6-9). All animals received grass-clover silage (320 g dry matter $(\mathrm{DM}) / \mathrm{kg} ; 182 \mathrm{~g}$ crude protein $(\mathrm{CP}) / \mathrm{kg} \mathrm{DM} ; 78 \mathrm{~g}$ absorbable protein at the duodenum (APD; RAP, 1999)/kg DM; 5.9 MJ net energy lactation (NEL; RAP, 1999)/kg DM), meadow hay (857 g DM/kg; 73 g CP/kg DM; 68 g APD $/ \mathrm{kg}$ $\mathrm{DM}$; 4.7 MJ NEL/kg DM), a pelleted concentrate (composed of barley and straw meal) and a mineral premix (Table 1). The mineral mixture was either provided

TABLE 1

Composition of the diets used in Experiments I and II

\begin{tabular}{|c|c|c|c|c|c|c|}
\hline \multirow[b]{2}{*}{ Treatment } & \multicolumn{2}{|c|}{ Experiment I } & \multicolumn{4}{|c|}{ Experiment II } \\
\hline & control & $\begin{array}{c}\text { +essential } \\
\text { oils }\end{array}$ & control & + saponins & + tannins & $\begin{array}{c}+ \text { soyabean } \\
\text { meal }\end{array}$ \\
\hline \multicolumn{7}{|l|}{ Ingredients, $\mathrm{g} / \mathrm{kg} \mathrm{DM}$} \\
\hline Forage & 746.0 & 746.0 & 728.6 & 728.1 & 727.8 & 727.9 \\
\hline grass silage & 538.6 & 538.6 & 689.4 & 688.9 & 688.6 & 688.7 \\
\hline meadow hay & 207.4 & 207.4 & 39.2 & 39.2 & 39.2 & 39.2 \\
\hline Concentrate & 254.0 & 254.0 & 271.4 & 271.9 & 272.2 & 272.1 \\
\hline barley & 242.1 & 242.1 & 257.2 & 257.6 & 257.9 & 193.2 \\
\hline straw meal & 4.7 & 4.7 & 4.9 & 4.8 & & 4.9 \\
\hline saponin-rich extract & & & & 0.1 & & \\
\hline tannin-rich extract & & & & & 4.9 & \\
\hline soyabean meal & & & & & & 64.6 \\
\hline Mineral premix ${ }^{1}$ & 7.2 & 7.1 & 9.3 & 9.4 & 9.4 & 9.4 \\
\hline Essential oil-rich extract ${ }^{2}$ & & 0.1 & & & & \\
\hline \multicolumn{7}{|c|}{ Composition of the complete diets ${ }^{3}$} \\
\hline DM, g/kg wet weight & & 418 & 383 & 383 & 383 & 383 \\
\hline organic matter, g/kg DM & & 978 & 923 & 926 & 930 & 927 \\
\hline crude protein, $\mathrm{g} / \mathrm{kg} \mathrm{DM}$ & & 140 & 162 & 160 & 160 & 185 \\
\hline $\mathrm{NDF}, \mathrm{g} / \mathrm{kg} \mathrm{DM}$ & & 431 & 407 & 408 & 402 & 400 \\
\hline $\mathrm{NEL}^{4}, \mathrm{MJ} / \mathrm{kg}$ & & 6.08 & 6.26 & 6.22 & 6.23 & 6.32 \\
\hline $\mathrm{APD}^{4}, \mathrm{~g} / \mathrm{kg} \mathrm{DM}$ & & 81.7 & 95.4 & 94.3 & 94.7 & 108.0 \\
\hline
\end{tabular}

${ }_{1}^{1}$ mineral premix containing per kg: Ca 140 g, P 70 g, Mg 30 g, Na 40 g, vit. A 1'000'000 IU, vit. $\mathrm{D}_{3}$ 200 '000 IU, vit. E 1'500 mg

${ }^{2}$ added to the mineral premix

${ }^{3}$ calculated either from analysis of grass silage, hay and complete concentrates or from tabulated values (RAP, 1999)

${ }^{4} \mathrm{NEL}$ - net energy lactation; APD - absorbable protein at the duodenum (RAP, 1999) 
unchanged (control treatment) or supplemented with $0.1 \mathrm{~g} / \mathrm{kg}$ feed DM of Digestarom $1319^{\circledR}$ powder (Micro-Plus, Stadtoldendorf, Germany). According to the manufacturer, the product consisted of finely milled herbs and spices and their extracts, and was characterized by its content of essential oils. The percentage used was approximately corresponding to the amount of $2 \mathrm{~g}$ per cow per day recommended by manufacturer. Both diets were designed to be deficient in APD with the calculated level of deficiency being set to $10 \%$ of assumed requirements for absorbable protein. Because forage formed the main diet component, the amount of feed allocated to cover target levels in net energy and protein almost reached the assumed amount of ad libitum DM intake. The forage was manually filled into the troughs twice a day, and the concentrate was provided automatically five times a day. The mineral mixture was manually given into the bowl of the concentrate feeders once a day. Experiment I was performed with multiparous Brown Swiss dairy cows ( $3.6 \pm 1.2$ (mean \pm SD) lactations on average) being $14.4 \pm 9.3$ weeks in lactation. At the start of Experiment I, average liveweight was $624 \pm 65 \mathrm{~kg}$, and milk yield, fat and protein contents amounted to $24.9 \pm 4.1 \mathrm{~kg} / \mathrm{d}$, $4.03 \pm 0.43 \%$ and $3.15 \pm 0.21 \%$, respectively.

The design of Experiment II was based on an arrangement consisting of six replicates of four treatments. Data was obtained in three subsequent series with two cows per treatment and series. The animals were allocated to the respective treatment groups regarding milk yield and liveweight. Following a week without treatment feeding (Week 0), treatment diets were fed for 3 weeks, with the first two weeks serving for adaptation and Week 3 for intensive measurements (collection week). All animals received the same forage mainly containing grass-clover silage (DM $365 \mathrm{~g} / \mathrm{kg}$; per kg DM: CP $185 \mathrm{~g}$; APD $76 \mathrm{~g}$; NEL $5.8 \mathrm{MJ}$ ) and a small amount of meadow hay (DM $880 \mathrm{~g} / \mathrm{kg}$; per kg DM: CP $103 \mathrm{~g}$; APD $80 \mathrm{~g}$; NEL $5.2 \mathrm{MJ}$ ). Three concentrates (control and those supplemented with plant extracts) consisted of the same proportions of barley and a mineral mixture (Table 1). A third component of the concentrates was straw meal, which was replaced partly (+saponins treatment) or totally (+tannins treatment) by the plant extracts rich in saponins and tannins, respectively. Saponins originated from a Yucca schidigera extract (Micro-Aid ${ }^{\circledR}$; Distributors Processing Inc., Porterville, CA, USA; Valdez et al., 1986) and tannins were of a hydrolysable form originating from a Castanea sativa wood extract (Prodex ${ }^{\circledR}$; Valorex-Prodex SA, Combourtille, France; Decruyenaere et al., 1996). The dietary proportions (0.1 and 4.9 $\mathrm{g} / \mathrm{kg} \mathrm{DM}$ of the saponin-rich and the tannin-rich product, respectively, equivalent to $2 \mathrm{mg} / \mathrm{kg}$ of saponins and $1 \mathrm{~g} / \mathrm{kg}$ tannins, following manufacturers' statements), corresponded to doses that were tested earlier in lambs (Śliwiński et al., 2002b). More information on the two extracts used is given elsewhere (Śliwiński et al., 2002a). The fourth concentrate contained additional soyabean meal and was not supplemented with plant extracts. This diet was the only one calculated (RAP, 
1999) to completely cover requirements for absorbable protein whereas, like in Experiment I, the others were designed to be deficient in absorbable protein by $10 \%$. This experimental concept had been followed earlier in vitro (Śliwiński et al., 2002a) and in growing sheep (Śliwiński et al., 2002b) with the same plant extracts. The diets were dominated by grass-clover silage thus ensuring a sufficient supply of rumen-degradable protein in all groups (APDN; RAP, 1999). Net energy supply was sufficient when accounting for recommended (RAP, 1999) mobilization of body reserves of early lactating cows. As in Experiment I, forage was provided twice and concentrate five times per day. Experiment II was performed with four primiparous (one per treatment) and 20 multiparous Brown Swiss dairy cows ( $3.0 \pm 1.1$ lactations on average) being $7.4 \pm 5.1$ weeks in lactation. At the start of the experiment cows weighed $615 \pm 51 \mathrm{~kg}$ on average and had a milk yield of $26.9 \pm 5.2 \mathrm{~kg} / \mathrm{d}$ with $4.11 \pm 0.44 \%$ fat and $3.27 \pm 0.29 \%$ protein.

\section{Experimental techniques}

In both experiments animals were tethered, but were brought to an outside area every second day for $1 \mathrm{~h}$, except during the collection week in Experiment II. In Experiment I, liveweight was measured twice a week and weekly in Experiment II. Individual forage intake was continuously monitored using a feeding system equipped with electronic balances (Westfalia Landtechik, Oelde, Germany) combined with electronically controlled feeding doors (American Calan Inc., Northwood, NH, USA) registering intake at each access to the troughs. Feed samples were taken twice a week, immediately dried at $60^{\circ} \mathrm{C}$ for $48 \mathrm{~h}$ and milled through a $0.75 \mathrm{~mm}$ screen. Water consumption, which was unrestricted, was recorded in Experiment I by computer-assisted flow meters (Bürkert, Fluid control systems, Ingelfingen, Switzerland; tolerance $\pm 1 \%$ ). Milk yield was measured by an automatic milk recording system (Westfalia Landtechnik, Oelde, Germany). Proportionate milk samples were taken from four milkings per cow and week obtained in intervals of 3 and 4 days, except in the collection week of Experiment II where two milk samples were taken from each milking. Milk samples were conserved with Bronopol (BSM2 ${ }^{\circledR}, \mathrm{D} \& \mathrm{~F}$ Control, San Ramon, USA) and stored at $+4^{\circ} \mathrm{C}$ until analysis. The respective second milk sample in the collection week of Experiment 2 was not treated with Bronopol but immediately frozen at $-20^{\circ} \mathrm{C}$, later thawed and pooled to proportionate samples of the complete collection week and then frozen again for later $\mathrm{N}$ analysis.

In Experiment II, additionally three blood samples were obtained from each animal by puncture of the jugular vein in the early afternoon after $2 \mathrm{~h}$ of fasting. The respective first sample was taken on the day before Experiment II started (last day of Week 0), the second and third samples were obtained on the second and on the last day of the collection week (Week 3), respectively. The results of the 
latter two samples were later combined. At each sampling date three sub-samples were collected in special tubes containing heparin and immediately cooled on ice. Two of the sub-samples were centrifuged at $1^{\prime} 500 \mathrm{~g}$ and $+4^{\circ} \mathrm{C}$ for $15 \mathrm{~min}$, and plasma was stored either at $-70^{\circ} \mathrm{C}$ for later ammonia analysis or at $-20^{\circ} \mathrm{C}$ for urea determination. The third blood sub-sample was left untreated for haematocrit and haemoglobin analysis which was performed in order to monitor the unlikely case of haemolytic effects of saponins (Wang et al., 1999).

In Experiment II also total faecal and urinary excretion was recorded daily during the collection week. A sample of the mixed faeces was taken daily, stored at $-20^{\circ} \mathrm{C}$ and pooled after thawing to one sample at the end of the collection week. One sub-sample of the pooled faeces was frozen at $-20^{\circ} \mathrm{C}$ for $\mathrm{N}$ analysis and for manure storage, the other sub-sample was dried at $60^{\circ} \mathrm{C}$ for $48 \mathrm{~h}$ and milled through a $0.75 \mathrm{~mm}$ sieve. To separate urine from the faeces, waterproof fabric urinals were used. These were tightly attached around the vulva with the help of Velcro ${ }^{\circledR}$ tapes glued with Cyanolit (3M AG, Rüschlikon, Switzerland) onto the shaved, cleaned and defatted ( $96 \%$ ethanol) skin. At the end of the urinal a device separated urine into sub-samples either remaining non-acidified or being immediately acidified with $50 \mathrm{ml}$ of $5 \mathrm{M}$ sulphuric acid. All urine samples were frozen $\left(-20^{\circ} \mathrm{C}\right)$ after daily collection. Daily samples were pooled for the whole collection week and stored again at $-20^{\circ} \mathrm{C}$ until being analysed or subjected to manure storage (non-acidified samples). Both experiments were carried out in accordance with the Swiss guidelines for animal welfare.

For the storage measurements in Experiment II, complete manure (in this case undiluted slurry) was produced from the thawed excreta of 16 out of the 24 cows (four replicates per treatment). Faeces and urine were mixed proportionately to the actually excreted quantities to produce the animal-specific complete manures. The storage technique as described by Estermann et al. (2002) was applied. Briefly, one sample of each homogenized material was immediately frozen for later analysis of initial manure composition, while the other material was divided into eight replicates of $800 \mathrm{~g}$ each. These were stored in 1.8-1 open glass cylinders with an emitting surface of $99 \mathrm{~cm}^{2}$ for $1,2,4$ and 8 weeks, respectively, in two replicates per animal. The averages of ambient temperature and humidity during storage were $20.7 \pm 0.4^{\circ} \mathrm{C}$ and $55.5 \pm 10.6 \%$, respectively. At the end of the respective time periods, weight losses of the vessels were recorded, their contents were homogenized, and samples for analysis were drawn and frozen.

\section{Chemical analyses}

Contents of DM and organic matter in feed, faeces and manure (only DM) were analysed by an automatic muffle furnace (TGA 500, Leco Instruments, 
St. Joseph, MI, USA) according to standard procedures (Naumann and Bassler, 1997). Contents of neutral detergent fibre (NDF) were determined as recommended by Van Soest et al. (1991) with the use of heat stable $\alpha$-amylase. For N determination in feed, non-dried faeces, acidified urine and homogenized fresh and stored manure an automatic C/N-Analyser (Leco-Analyser Type FP-2000, Leco instruments, St. Joseph, MI, USA) was applied. Concentrations of $\mathrm{NH}_{4}^{+}{ }^{-} \mathrm{N}$ in manure were analysed as total ammonia $\mathrm{N}$ by $\mathrm{MgO}$ distillation (Amberger et al., 1982). Urinary urea was enzymatically determined after dilution (1:100) with deionised water using the test kit 0736855 (Roche diagnostics, Basle, Switzerland) on an automatic photometer (Cobas Mira, Roche Diagnostics, Basle, Switzerland). For analysis of contents of fat, protein, lactose and urea in the Bronopol ${ }^{\circledR}$ conserved milk an infrared method was used (Milkoscan 4000, Foss Electric, Hillerød, Denmark). Somatic cell count was determined fluoroopto-electronically with the Fossomatic 400 (Foss Electric). The analysis of whole blood and blood plasma was performed with commercial test kits on an automatic photometer (Cobas Mira, Roche Diagnostics, Basle, Switzerland). In detail the kit 525-A (Sigma Diagnostics, Buchs, Switzerland) was used for haemoglobin, the kit 0736855 (Roche Diagnostics, Basle, Switzerland) for plasma urea and the kit 125857 (Boehringer, Mannheim, Germany) for plasma ammonia. The haematocrit was calculated after $5 \mathrm{~min}$ of centrifugation in a haematocrit centrifuge (Adams Autocrite ${ }^{\mathrm{TM}}$, Clay-Adams, Inc., New York, USA) by using a $75 \mathrm{~mm} / 75 \mu \mathrm{l}$ haematocrit capillary sealed with special wax (9120101, Hirschmann Laborgeräte GmbH, Eberstadt, Germany).

\section{Statistical analyses}

In Experiment I the initial values (Week 0) were compared with data of the first and second period by treating them as repeated measures. For these analyses the MIXED-procedure of SAS (version 6.12, SAS Institute Inc., Cary, NC, USA) was applied according to Littell et al. (1998) regarding the effects of diet, repetition, period and diet $\times$ period interaction, with period as repeated effect and cow as subject. Week means were used for all statistical evaluations in Experiment II. All data available from the initial period (Week 0) and the collection period (Week 3) were subjected to analysis of variance by ANOVA using the GLM procedure of SAS considering treatment (diet) and series as effects. Multiple comparisons of the means were carried out by the Tukey procedure. Comparisons within the same animal between the initial values (Week 0) and collection period values (Week 3 ) as well as the statistical analysis of the means over the whole manure storage period were conducted similarly as in Experiment I by the MIXED-procedure statement. In the tables, mean values and standard errors of the mean (SEM) are presented. 


\section{RESULTS}

\section{Experiment I}

Before the start of Experiment I (Week 0) there were no significant differences in performance of the groups later assigned to the two treatments (Table 2). Also the effects of supplementing the plant extract rich in essential oils remained without significant effect on DM intake, water intake $(85 \pm 26 \mathrm{vs} 81 \pm 19 \mathrm{~kg} / \mathrm{d}$, on average in control and supplemented group; data not shown in Table), liveweight, milk yield and milk composition. Dry matter intake and liveweight remained quite constant throughout the experiment. Milk yield, milk protein yield and contents of lactose and urea slightly decreased with time while contents of protein and fat showed a weak increase from Week 0 to the first and the second period regardless of treatment sequence. Compared to the requirements, as calculated from actual feed intake, milk yield and liveweight, supply of absorbable protein was deficient by 5-7\% in Weeks $1-4$ whereas no lack was obvious in Weeks 6-9. Both diets always provided sufficient amounts of net energy (Table 2) and rumen-degradable protein (data not shown).

\section{Experiment II}

In Experiment II daily DM intake remained relatively constant with $18.0 \pm 0.51$, $17.2 \pm 0.51$ and $17.3 \pm 0.51$ across all groups in Weeks 1,2 and 3, respectively (Table 3). In liveweight no significant group differences were found, and there was no obvious liveweight change during Experiment II. Differences among groups in milk yield, milk protein yield and contents of fat, protein and lactose were not significant. In the group receiving soyabean meal there was a slight increase in milk yield and milk protein yield with time whereas levels tended to decrease in all other groups. In the control group, but not in the supplemented groups, this trend was also obvious for protein and fat content of the milk. Somatic cell counts were non-significantly elevated with the tannin-rich supplement due to two out of six cows with elevated counts. Accordingly, this was probably the result of random occurrence of mastitis in that group similar to the high pre-experimental value in the cows later receiving the soyabean meal diet. In the treatments control, +saponins and +tannins the effective supply of absorbable protein with the respective experimental diets was deficient by $0-9 \%$ compared to the requirements. There were certain treatment differences (significant only in Week 1) between control and the saponin supplemented diet, but absorbable protein supply relative to requirements was always highest in the soyabean-meal supplemented group (significant in Weeks 1 and 2). The latter group received absorbable protein in an amount which was always beyond calculated actual requirements. The same is 
TABLE 2

Performance, energy and protein supply of cows receiving diets with and without a plant extract rich in essential oils $(\mathrm{n}=8 \text {; Experiment } \mathrm{I})^{1}$

\begin{tabular}{|c|c|c|c|c|}
\hline $\begin{array}{l}\text { Treatment } \\
\text { sequence }^{2}\end{array}$ & $\begin{array}{c}1^{\text {st }} \text { control } \\
2^{\text {nd }}+\text { essential oils }\end{array}$ & $\begin{array}{c}1^{\text {st }}+\text { essential } \\
\text { oils } \\
2^{\text {nd }} \text { control } \\
\end{array}$ & $p$-value & SEM \\
\hline DM intake, $\mathrm{kg} / \mathrm{d}$ & \multicolumn{2}{|c|}{ Feed intake and liveweight } & & \multirow{3}{*}{0.64} \\
\hline weeks $1-4$ & 17.3 & 17.4 & 0.96 & \\
\hline weeks 6-9 & 17.7 & 17.0 & 0.44 & \\
\hline \multirow{4}{*}{$\begin{array}{c}\text { Liveweight, } \mathrm{kg} \\
\text { week } 0^{3} \\
\text { weeks } 1-4 \\
\text { weeks } 6-9\end{array}$} & & & & \multirow[t]{4}{*}{22.7} \\
\hline & 605 & 628 & 0.47 & \\
\hline & 594 & 620 & 0.40 & \\
\hline & 602 & 618 & 0.61 & \\
\hline \multicolumn{4}{|c|}{ Milk yield and composition } & \multirow{4}{*}{1.30} \\
\hline week 0 & 24.0 & 24.6 & 0.75 & \\
\hline weeks 1-4 & 22.5 & 22.5 & 0.97 & \\
\hline weeks 6-9 & 19.6 & 19.9 & 0.88 & \\
\hline \multicolumn{3}{|l|}{ Protein yield, g/d } & & \multirow{4}{*}{39.9} \\
\hline week 0 & 737 & 785 & 0.40 & \\
\hline weeks $1-4$ & 715 & 726 & 0.85 & \\
\hline weeks 6-9 & 678 & 666 & 0.84 & \\
\hline \multicolumn{3}{|l|}{ Protein content, $\mathrm{g} / \mathrm{kg}$} & & \multirow[t]{4}{*}{0.80} \\
\hline week 0 & 30.8 & 31.9 & 0.30 & \\
\hline weeks 1-4 & 31.9 & 32.3 & 0.70 & \\
\hline weeks 6-9 & 34.5 & 33.6 & 0.43 & \\
\hline \multicolumn{3}{|l|}{ Fat content, $\mathrm{g} / \mathrm{kg}$} & & \multirow[t]{4}{*}{1.36} \\
\hline week 0 & 40.5 & 40.8 & 0.87 & \\
\hline weeks $1-4$ & 39.3 & 39.9 & 0.74 & \\
\hline weeks 6-9 & 43.1 & 41.1 & 0.30 & \\
\hline \multicolumn{3}{|l|}{ Lactose content, $\mathrm{g} / \mathrm{kg}$} & & \multirow[t]{4}{*}{0.62} \\
\hline week 0 & 49.9 & 50.5 & 0.47 & \\
\hline weeks $1-4$ & 49.4 & 50.2 & 0.35 & \\
\hline weeks 6-9 & 48.6 & 49.2 & 0.56 & \\
\hline \multicolumn{3}{|l|}{ Urea content, $\mathrm{mmol} / \mathrm{l}$} & & \multirow[t]{4}{*}{0.161} \\
\hline week 0 & 4.15 & 3.80 & 0.13 & \\
\hline weeks $1-4$ & 4.18 & 3.90 & 0.21 & \\
\hline weeks 6-9 & 3.99 & 3.77 & 0.33 & \\
\hline \multicolumn{4}{|l|}{ Somatic cell count, $10^{3} / \mathrm{ml}$} & \multirow[t]{4}{*}{47.8} \\
\hline week 0 & 156 & 107 & 0.47 & \\
\hline weeks 1-4 & 197 & 165 & 0.64 & \\
\hline weeks 6-9 & 157 & 104 & 0.43 & \\
\hline \multicolumn{5}{|c|}{ Proportion of requirements for maintenance and milk yield actually covered by intake } \\
\hline \multirow{6}{*}{$\begin{array}{l}\text { Absorbable protein, \% } \\
\text { weeks } 1-4 \\
\text { weeks 6-9 } \\
\text { Net energy lactation, \% } \\
\text { weeks 1-4 } \\
\text { weeks 6-9 }\end{array}$} & & & & \multirow[t]{3}{*}{3.4} \\
\hline & 95 & 93 & 0.72 & \\
\hline & 102 & 99 & 0.43 & \\
\hline & & & & \multirow[t]{3}{*}{3.0} \\
\hline & 101 & 99 & 0.68 & \\
\hline & 108 & 104 & 0.37 & \\
\hline
\end{tabular}

${ }^{1} \mathrm{SEM}=$ standard error of the means. Least square means by treatment and period

${ }^{2} 1^{\text {st }}=$ weeks $1-4,2^{\text {nd }}=$ weeks $6-9$

${ }^{3}$ week before start of treatment feeding; all cows receiving the control diet

${ }^{4}$ corrected for energy content according to RAP (1999) 
TABLE 3

Performance, energy and protein supply of cows receiving diets with and without plant extracts rich in saponins and tannins $(\mathrm{n}=6 \text {; Experiment } \mathrm{II})^{1}$

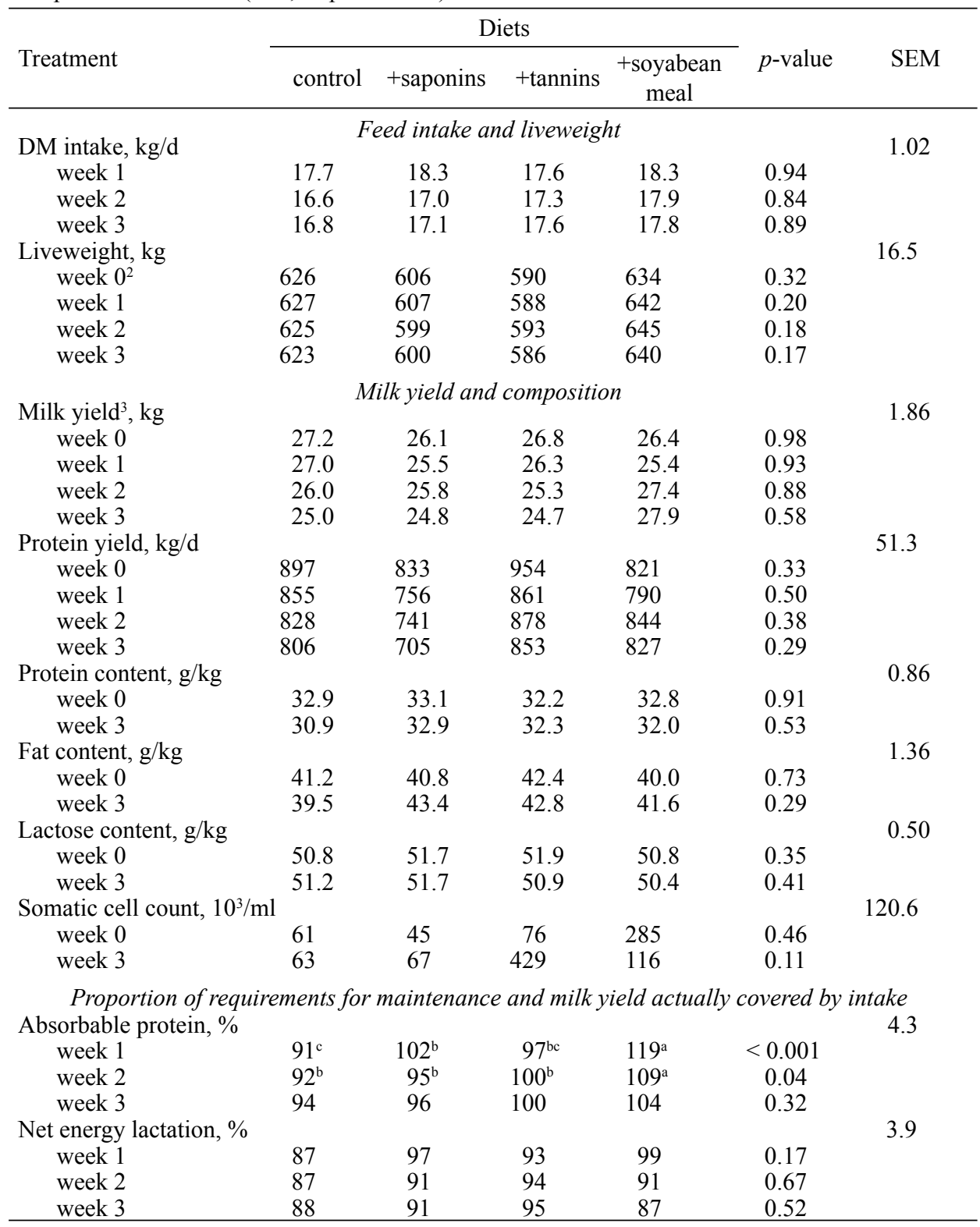

${ }^{1} \mathrm{SEM}=$ standard error of the means. Least square means by treatment and period. LS means in the same line without common superscript are significantly different $(p<0.05)$

${ }^{2}$ week before start of treatment feeding; all cows receiving the control diet

${ }^{3}$ corrected for energy content according to RAP (1999) 
valid for rumen-degradable protein in all treatment groups (data not shown). Net energy supply was $1-13 \%$ below actual requirements, this being within the range recommended to allow cows to mobilize energy from body reserves at the start of the lactation, and was not significantly different among treatments.

Haematocrit and haemoglobin concentration in blood were not significantly affected by the dietary treatments (data not shown). Before Experiment II started, the mean haemoglobin concentration was $11.4 \mathrm{~g} / \mathrm{l}$ and, after 3 weeks of feeding with the control, saponin, tannin and soyabean meal supplemented diets, haemoglobin concentrations were $11.1,10.7,10.8$ and $11.9 \mathrm{~g} / 1$, respectively. The respective values for haematocrit were initially $33.1 \%$, and $30.2,31.1,31.4$ and $33.1 \%$, respectively, for the four treatment groups in Week 3 . These results ruled out any major haemolytic effect of the secondary plant constituents used.

No significant differences were found in apparent digestibilities of organic matter and NDF (Table 4) which, on average, accounted for $0.76 \pm 0.03$ and $0.68 \pm 0.06$ of intake, respectively. However, the apparent $\mathrm{N}$ digestibility was significantly lower in the saponin-supplemented group than in the soyabean meal group, and the other two groups had low values similar to the saponin-supplemented group.

The plasma urea concentration was not significantly affected by the treatments (Table 4). However, in all diets with reduced protein supply, the concentration of plasma urea slightly decreased during the experiment (-17\% on average) whereas with the soyabean meal diet, where the values initially were lower, a slight increase $(+11 \%)$ was noted. Also for plasma ammonia concentration no significant treatment differences were found (data not shown). Initially, ammonia concentration was $33.8 \mu \mathrm{mol} / 1$ on average, whereas the final values were $24.7,31.2,31.9$ and $34.3 \mu \mathrm{mol} / 1$ for the control, saponin, tannin and soyabean meal diets, respectively, thus showing similar trends as plasma urea concentrations. In the collection period urinary urea $\mathrm{N}$ concentration was significantly reduced in the saponin-supplemented group compared to the soyabean meal group and the control. The tanninsupplemented group had intermediate values. Milk urea concentration decreased from Week 0 to the collection week with the control, the saponin-supplemented and the tannin-supplemented diet, and was then significantly lower than with the soyabean meal diet. Concerning daily amounts of urea $\mathrm{N}$ excreted through urine and milk, values in Week 3 were significantly lower with the groups supplemented with the plant extracts and in control (only urinary urea $\mathrm{N}$ ) than in the soyabean meal group. The latter group excreted $143 \mathrm{~g}$ urea $\mathrm{N} / \mathrm{d}$ in total whereas values with the control, saponin and tannin diets were only 98,96 and $107 \mathrm{~g} / \mathrm{d}$.

Nitrogen intake was significantly higher with the soyabean meal diet than with the control and the saponin-supplemented diet, and, due to slightly differing DM intakes, non-significantly higher than with the tannin-supplemented diet. In line with the high $\mathrm{N}$ intake, the urinary $\mathrm{N}$ excretion was also significantly higher with the soyabean meal diet than with the other diets, while the $\mathrm{N}$ excretions with 
TABLE 4

Nutrient digestibilities, urea in blood plasma, urine and milk, and nitrogen balance of cows receiving diets with and without plant extracts rich in saponins and tannins $(n=6 \text {; Experiment II })^{1}$

\begin{tabular}{|c|c|c|c|c|c|c|}
\hline \multirow[b]{2}{*}{ Treatment } & \multicolumn{4}{|c|}{ Diets } & \multirow[b]{2}{*}{$p$-value } & \multirow[b]{2}{*}{ SEM } \\
\hline & control & + saponins & + tannins & $\begin{array}{l}\text { +soyabean } \\
\text { meal }\end{array}$ & & \\
\hline \multicolumn{7}{|c|}{ Apparent nutrient digestibility coefficients (Week 3) } \\
\hline Organic matter & 0.75 & 0.75 & 0.76 & 0.76 & 0.84 & 0.008 \\
\hline NDF & 0.68 & 0.67 & 0.70 & 0.67 & 0.46 & 0.013 \\
\hline $\mathrm{N}$ & $0.67^{\mathrm{ab}}$ & $0.67^{\mathrm{b}}$ & $0.69^{\mathrm{ab}}$ & $0.72^{\mathrm{a}}$ & 0.04 & 0.013 \\
\hline \multicolumn{7}{|c|}{ Body fluid urea $N$ concentrations and excretions } \\
\hline week $0, \mathrm{mmol} / 1$ & 7.95 & 7.62 & 7.29 & 6.64 & 0.21 & 0.434 \\
\hline week $3, \mathrm{mmol} / \mathrm{l}$ & 6.16 & 6.25 & 6.55 & 7.40 & 0.17 & 0.413 \\
\hline \multicolumn{7}{|l|}{ Urinary urea } \\
\hline week $3, \mathrm{mmol} / \mathrm{l}$ & $154^{\mathrm{ab}}$ & $129^{\mathrm{b}}$ & $141^{\mathrm{ab}}$ & $176^{\mathrm{a}}$ & 0.01 & 9.1 \\
\hline week $3, \mathrm{~g} \mathrm{~N} / \mathrm{d}$ & $95^{\mathrm{b}}$ & $93^{\mathrm{b}}$ & $104^{\mathrm{b}}$ & $139^{\mathrm{a}}$ & $<0.001$ & 6.6 \\
\hline \multicolumn{7}{|l|}{ Milk urea } \\
\hline week $0, \mathrm{mmol} / 1$ & 5.70 & 5.66 & 6.04 & 5.86 & 0.66 & 0.331 \\
\hline week $3, \mathrm{mmol} / \mathrm{l}$ & $4.89^{b}$ & $4.69^{\mathrm{b}}$ & $4.79^{b}$ & $5.62^{\mathrm{a}}$ & 0.04 & 0.331 \\
\hline week $3, \mathrm{~g} \mathrm{~N} / \mathrm{d}$ & $3.4^{\mathrm{ab}}$ & $3.1^{\mathrm{b}}$ & $3.1^{\mathrm{b}}$ & $4.3^{\mathrm{a}}$ & 0.02 & 0.27 \\
\hline \multicolumn{7}{|c|}{ Nitrogen balance in Week $3, \mathrm{~g} / d$} \\
\hline $\mathrm{N}$ intake ${ }^{2}$ & $\begin{array}{r}417^{\mathrm{b}} \\
(401)\end{array}$ & $\begin{array}{r}417^{\mathrm{b}} \\
(402)\end{array}$ & $\begin{array}{c}430^{\mathrm{ab}} \\
(403)\end{array}$ & $\begin{array}{r}510^{\mathrm{a}} \\
(491)\end{array}$ & $\begin{array}{c}0.02 \\
(0.18)\end{array}$ & $\begin{array}{c}22.0 \\
(32.2)\end{array}$ \\
\hline Faecal N ${ }^{2}$ & $\begin{array}{c}137 \\
(127)\end{array}$ & $\begin{array}{c}138 \\
(126)\end{array}$ & $\begin{array}{c}133 \\
(122)\end{array}$ & $\begin{array}{c}142 \\
(133)\end{array}$ & $\begin{array}{c}0.94 \\
(0.92)\end{array}$ & $\begin{array}{l}10.6 \\
(11.7)\end{array}$ \\
\hline Urinary $\mathrm{N}^{2}$ & $\begin{array}{c}141^{\mathrm{b}} \\
\left(138^{\mathrm{ab}}\right)\end{array}$ & $\begin{array}{l}138^{\mathrm{b}} \\
\left(133^{\mathrm{ab}}\right)\end{array}$ & $\begin{array}{c}135^{\mathrm{b}} \\
\left(130^{\mathrm{b}}\right)\end{array}$ & $\begin{array}{l}193^{\mathrm{a}} \\
\left(186^{\mathrm{a}}\right)\end{array}$ & $\begin{array}{r}<0.001 \\
(0.03)\end{array}$ & $\begin{array}{c}9.1 \\
(12.6)\end{array}$ \\
\hline Milk N & 124 & 114 & 115 & 141 & 0.25 & 10.3 \\
\hline $\mathrm{N}$ balance & 15 & 27 & 47 & 33 & 0.11 & 8.8 \\
\hline \multicolumn{7}{|c|}{ Nitrogen utilization in Week 3} \\
\hline Milk N, \% of intake & 30.1 & 27.3 & 26.7 & 27.4 & 0.56 & 1.79 \\
\hline
\end{tabular}

${ }^{1} \mathrm{SEM}=$ standard error of the means. Least square means by treatment and period. Means in the same line without common superscript are significantly different $(p<0.05)$

${ }^{2}$ values in brackets: averages of those $4 \times 6$ cows whose manure was subjected to storage treatment (Table 5)

faeces and milk were similar for all groups. Quantitatively, treatment differences in $\mathrm{N}$ intake and excretion with faeces and urine were similar in the sub-samples of the four cows per treatment selected for the subsequent manure storage trial (values in brackets) compared to the differences in the complete dataset. Nitrogen balance was overall positive without significant differences among diets, and the $\mathrm{N}$ utilization for milk $\mathrm{N}$ excretion was also not clearly differing although showing the numerically highest percentage for the unsupplemented control diet. 
Table 5 shows the effects of the diets on manure composition and changes occurring during storage. Dry matter concentration increased during storage, but did not show any significant differences between the treatments in the first 4 weeks. After 8 weeks of storage a trend was visible, with the highest DM content being found for the control group followed by the soyabean meal group and lowest for the diets supplemented with the plant extracts. The numerically lowest initial manure $\mathrm{N}$ concentration was found with the tannin-supplemented diet and the soyabean meal diet, followed by the saponin-supplemented diet and the control diet with the highest value. After 8 weeks of storage the opposite order was observed. The initial $\mathrm{NH}_{4}^{+}$concentration per $\mathrm{kg} \mathrm{DM}$ was significantly lowest with the saponin-enriched diet compared to all others groups. After 1 week of storage ammonia concentration increased in every treatment group, this particularly in the soyabean meal group (significantly higher levels those in saponin-supplemented and control groups). After 2 weeks of storage similar treatment differences as after 1 week were found, but ammonia concentrations in DM now had declined and were close to the value initially found in the control group. From 4 weeks of storage on, treatment differences were no longer significant. When ammonia $\mathrm{N}$ was related to total manure $\mathrm{N}$, this ratio was significantly lowest in the manure from the saponin-supplemented group in comparison to the other groups. Differences to the control and the tannin-supplemented group were no longer significant after 1 week of storage, but the difference to the soyabean meal supplemented group remained. Differences in ammonia $\mathrm{N}$ proportion of total manure $\mathrm{N}$ declined from then on and were not significant any more until to the end of storage. Gaseous $\mathrm{N}$ losses during the 8 weeks of manure storage, as a percentage of initially present manure $\mathrm{N}$, were higher for the control than for all other groups $(p=0.06)$, with the numerically lowest values found with the tannin-supplemented diet. This was even more pronounced when the $\mathrm{N}$ losses were related to the amount of $\mathrm{N}$ daily excreted by the cows. Accordingly, $\mathrm{N}$ emissions were only about half of control with the tanninsupplemented diet and intermediate with the other two diets ( 74 and $85 \%$ of the $\mathrm{N}$ emission of control with the saponin and the soyabean meal-supplemented diets).

\section{DISCUSSION}

\section{Effects of the plant extracts on performance}

The present study tested three plant extracts characterized by secondary plant constituents which are known to influence ruminal $\mathrm{N}$ degradation and are hypothesized to improve protein supply at the duodenum and performance of ruminants. However, performance was not clearly altered by the extracts studied although there is some evidence in the literature that supplementation of certain diets with 
TABLE 5

Changes in manure composition and storage nitrogen loss from manure of cows receiving diets with and without plant extracts rich in saponins and tannins $(n=4 \text {; Experiment II })^{1}$

\begin{tabular}{|c|c|c|c|c|c|c|}
\hline \multirow[b]{2}{*}{ Treatment } & \multicolumn{4}{|c|}{ Diets } & \multirow[b]{2}{*}{$p$-value } & \multirow[b]{2}{*}{ SEM } \\
\hline & control & + saponins & $+\operatorname{tannins}$ & $\begin{array}{c}+ \text { soyabean } \\
\text { meal }\end{array}$ & & \\
\hline
\end{tabular}

$\mathrm{DM}, \mathrm{g} / \mathrm{kg}$

Manure composition during storage

Initial

1 week of storage

100

93

97

92

2 weeks of storage

112

104

103

107

0.38

$117 \quad 111$

114

113

0.32

4 weeks of storage

127

119

122

120

0.66

$161^{\text {(a) }} \quad 151^{(\mathrm{bc})}$

$149^{(\mathrm{c})}$

$158^{\text {(ab) }}$

0.40

8 weeks of storage

$\mathrm{N}, \mathrm{g} / \mathrm{kg} \mathrm{DM}$

Initial

1 week of storage

43.6

40.3

36.3

36.8

0.06

2 weeks of storage

36.7

37.0

41.3

36.0

0.11

37.6

36.9

38.6

39.2

0.36

31.4

31.5

33.1

36.1

0.89

18.5

22.3

26.3

22.1

0.45

8 weeks of storage

$23.9^{\mathrm{a}}$

$15.2^{\mathrm{b}}$

$21.9^{\mathrm{a}}$

$23.2^{\mathrm{a}}$

0.14

Initial

$27.8^{\mathrm{b}}$

$25.8^{\mathrm{b}}$

$30.4^{\mathrm{ab}}$

$33.4^{\mathrm{a}}$

0.005

1 week of storage

$23.7^{\text {(b) }}$

$22.7^{\text {(b) }}$

$25.2^{\text {(ab) }}$

$29.1^{\text {(a) }}$

0.03

19.6

18.9

20.6

23.5

0.08

9.5

10.9

12.0

10.1

0.29

8 weeks of storage

$\mathrm{NH}_{4}^{+}-\mathrm{N}, \mathrm{g} / \mathrm{kg}$ of total $\mathrm{N}$

Initial

493

307

503

0.78

2.30

1 week of storage

$640^{\mathrm{b}}$

$604^{\mathrm{b}}$

$503^{\mathrm{a}}$

$519^{a}$

0.01

$512 \quad 503$

$590^{\mathrm{b}}$

$785^{\mathrm{a}}$

0.03

2 weeks of storage

514

524

0.47

4 weeks of storage

491

504

605

0.94

444

409

374

536

0.75

Manure nitrogen loss during 8 weeks of storage

$\mathrm{N}$ loss, $\mathrm{g} / \mathrm{kg}$ initial manure $\mathrm{N} \quad 609^{(\mathrm{a})} \quad 456^{(\mathrm{ab})} \quad 336^{(\mathrm{b})} \quad 436^{(\mathrm{b})}$

0.06

67.6

$\mathrm{N} \operatorname{loss}^{2}$, g/animal/d

$163^{\mathrm{a}}$

$120^{\mathrm{ab}}$

$81^{\text {b }}$

$139^{\mathrm{ab}}$

0.04

17.9

${ }^{1} \mathrm{SEM}=$ standard error of the means. Least square means by treatment and period. Means in the same line without common superscript are significantly different $(p<0.05$, or $p<0.1$ in cases where the superscripts are displayed in brackets)

${ }^{2} \mathrm{~N}$ loss from the amount of faeces daily excreted per cow when subsequently stored as manure for 8 weeks 
moderate amounts of saponins and tannins may improve performance. By adding the same saponin-rich product as used in the present experiment, Kil et al. (1994) observed an increased milk yield while several other studies (e.g., Valdez et al., 1986; Corbellini et al., 2000) failed to show effects of Yucca extract on milk yield. Kobeisy et al. (2000) pointed out that dietary additions of hydrolysable tannins, as used in the present study, may increase milk yield. The same was true for an increased dietary proportion of groundnut skins, which also contain hydrolysable tannins (West et al., 1993). The groundnut skin supplementation additionally improved milk fat content, but reduced milk protein content. Similar to the present study, the same saponin- and tannin-rich extracts had no significant effect on organic matter and fibre digestibility as well as on $\mathrm{N}$ utilization of lambs (Śliwiński et al., 2002b).

The diets used in the present experiments were designed to cover net energy requirements to the extent recommended (RAP, 1999). All diets, except the soyabean meal supplemented diet in Experiment II, were intended to be deficient in supply of absorbable protein by $10 \%$ compared to requirements (RAP, 1999) in order to provoke protein-related effects of the supplements. In both experiments, initially there was a clear deficiency in absorbable protein approximately corresponding to the level targeted, but deficiency declined with the duration of the experiments. Also the difference in absorbable protein supply relative to requirements between control, saponin and tannin supplemented diets on one hand and the soyabean meal group on the other hand decreased in Experiment II with on average 22, 13 and 7\% in Weeks 1, 2 and 3, respectively, and the difference was only significant in Weeks 1 and 2 . This was mostly the result of a certain decline in milk yield at relatively unchanged feed intake. Therefore the lack of significant effects of the supplementation of the plant extracts on performance might either have resulted from a lack of efficiency or from the fact that protein deficiency in the cows did not last long enough to cause clear effects. However, in the soyabean meal supplemented group in Experiment II there was at least a non-significant trend towards maintaining performance better over time than in control. Since this was not observed in the saponin and tannin supplemented diets it can be stated that their efficacy was not sufficiently high to close the gap in absorbable protein supply between control and the soyabean-meal supplemented diet.

A further mechanism affecting performance could have been particularly expected from the product characterized by essential oils used in Experiment $I$, as this product also contained various herbs and spices (not specified in detail by the manufacturer). Herbs may improve palatability of the feed while essential oils could in turn impair palatability (reviewed by Wallace et al., 2002). This could indirectly affect performance by varying feed intake. However, the treatment groups in Experiment I did not differ in actual feed intake and performance although the cows were fed quasi ad libitum which is also indicated by the frequent but moderate refusals. 


\section{Effects of saponin-rich and tannin-rich extracts on digestion, metabolism and losses of nitrogen}

Saponins, tannins, and plant extracts rich in these secondary constituents are known to prevent rumen ammonia formation by different modes of action (reviewed by Makkar, 1993; Śliwiński et al., 2002a,b). Saponins are probably mostly effective through inhibiting ruminal urease and protease activities whereas the effect of the tannins is assumed to mainly come from their ability to form complexes with feed protein and endogenous proteins (McSweeney et al., 2001). Concentrations in blood, urine and milk of urea, which is formed from ammonia in the liver, were not clearly different from the unsupplemented control diet when supplementing both plant extracts, but there was a weak trend towards lower urea $\mathrm{N}$ excretion with urine and milk. As expected, differences to the soyabean-meal supplemented group were far greater due to the higher $\mathrm{N}$ supply with that diet. Reductions of milk urea N, blood urea $\mathrm{N}$ or blood ammonia $\mathrm{N}$ concentrations by supplementation of diets with Yucca schidigera extract have been reported in the majority of the experiments (e.g., Hussain and Cheecke, 1995; Corbellini et al., 2000). Evidence in the literature for the effects of hydrolysable tannins on blood urea $\mathrm{N}$ is controversial with either reduced (Hill et al., 1987) or elevated (Kobeisy et al., 2000) levels found. In general, urea $\mathrm{N}$ concentrations and excretions may be used as easily-accessible indicators of the efficiency of the plant extracts.

Like in the present study, certain shifts from urine $\mathrm{N}$ to faecal $\mathrm{N}$ with supplementary plant extracts were repeatedly observed and mostly took place without affecting $\mathrm{N}$ balance. This includes findings in lambs (Śliwiński et al., 2002b) offered the same products as investigated in the present study, steers fed peanut skin tannin (Hill et al., 1987) and goats receiving dietary shinnery oak (Villena and Pfister, 1990). By contrast, Hristov et al. (1999) noted in heifers fed supplements of Yucca extract even slightly increased urinary $\mathrm{N}$ excretions. The ratio of urine $\mathrm{N}$ to faecal $\mathrm{N}$ is one decisive factor determining ammonia emission from manure (Castillo et al., 2000), and is closely related to body urea metabolism (Kröber et al., 2000), thus explaining at least part of the group differences found in manure storage in the present study. However, despite the only moderate treatment differences in urine $\mathrm{N}$ to faecal $\mathrm{N}$ proportion between the unsupplemented control and the two supplemented diets in Experiment II, the manure from the control cows showed a high inclination for gaseous $\mathrm{N}$ emission during manure storage which was reduced by the saponin-rich extract and particularly by the tannin-rich extract. This confirms preliminary findings of a reduced ammonia emission in sheep fed the same plant extracts rich in tannins and saponins (Śliwiński et al., 2002b). Also Grabber et al. (2002) pointed out that the use of feeds containing tannins might increase the stability of $\mathrm{N}$ in manure. The tannins still may have been effective in binding proteins even in the manure (Van Soest et al., 1987) complexing 
for instance proteinous digestive enzymes (McSweeney et al., 2001) which are otherwise easily degraded to ammonia in the hindgut and outside of the digestive tract. This effect may be noticeable only after a certain time of storage has passed because in the manure the urinary urea is at first transformed into ammonia. For saponins in turn, Preston et al. (1987) found that caecal urease activity in rats was lower when Yucca saponin was added to diets high in protein or to urea supplemented diets. Provided the saponins are still active in the hindgut, they might also be able to inhibit microbial urease activity after excretion with faeces. This would explain the findings of the present study where the ammonium concentration in the manure was initially lower with the saponin supplemented diet than with the control diet, thus limiting the amount of potentially emitted N. Yucca extract may have a further favourable side-effect by reducing odour emissions from fresh manure as described in pigs by Miner (1995). Unexpectedly, the gaseous N losses from the manure of the cows fed soyabean meal were lower than those of the control cows receiving the low-protein diet. Protein in soyabean meal is of low degradability due to heat treatment and might have escaped rumen degradation to a greater extent as the protein of the basal diet (mainly protein from grass silage; RAP, 1999). However, the soyabean-meal fed cows still showed higher proportions of urinary $\mathrm{N}$ to total $\mathrm{N}$ than the control cows.

\section{CONCLUSIONS}

The present results illustrate that the products tested do not clearly influence performance of dairy cows when receiving diets sufficient or slightly deficient in absorbable protein. This could be different in diets with clearer protein deficiency. However, a promising field of application of the tannin-rich and, slightly less so, the saponin-rich product are dietary measures to reduce ammonia emission from the manure. To extend the knowledge on reducing ammonia emission from livestock husbandry through plant extracts in different types of diet further experiments are necessary. The extracts could also be efficient when added directly to the manure, as shown for Yucca extract by Headon and Walsh (1993), but this fails to prevent $\mathrm{N}$ emissions directly following excretion of urine.

\section{ACKNOWLEDGEMENTS}

We owe thanks to Dr. H. Leuenberger and A. Felder for assistance in organizing and performing the experiments at the ETH experimental station Chamau. We are also grateful to M. Arnold, S.J. Dulęba, C. Kunz, A. Moses and R.H. Razminowicz for help in the laboratory. 


\section{REFERENCES}

Amberger A., Vilsmeier K., Gutser R., 1982. Stickstofffraktionen verschiedener Güllen und deren Wirkung im Pflanzenversuch. Z. Pflanz. Bodenk. 145, 325-336

Brooker J.D., Rakhmani S., O'Donovan L., Krause D.O., 2002. Effect of tannins and other secondary plant products on microbial populations and gut function. Reprod. Nutr. Develop. 42, Suppl. 1, S59

Castillo A.R., Kebreab E., Beever D.E., France J., 2000. A review of efficiency of nitrogen utilisation in lactating dairy cows and its relationship with environmental pollution. J. Anim. Feed Sci. 9, 1-32

Corbellini C.N., Introzzi C.A., Garbarino E., Capitanelli C., Auzmendi J., Marrodan M., 2000. Effects of a Yucca schidigera extract on milk yield and on reproductive efficiency in heifers and dairy cows. Rev. Med. Vet. 81, 189-194

Decruyenaere V., Remond D., Zimmer N., Poncet C., Jebri A., Thewis A., 1996. Effet des tanins de châtaignier sur la digestion in sacco et in vivo des matières azotées chez le ruminants. Renc. Rech. Rumin. 3, 93-96

Estermann B.L., Sutter F., Schlegel P.O., Erdin D., Wettstein H.-R., Kreuzer M., 2002. Effect of calf age and dam breed on intake, energy expenditure and excretion of nitrogen, phosphorus and methane of beef cows with calves. J. Anim. Sci. 80, 1124-1134

Grabber J., Broderick G., Russell M., Powell M., Rotz A., Muck R., Mertens D., Massingill L., 2002. Tannin-containing forages crops: A way to improve nitrogen use and profitability of dairy farms? U.S. Dairy Forage Research Center; 20th Anniversary; Informational Disc. http: //www.dfrc.ars.usda.gov/cd/ posters/Tannin\%20dafosym.pdf

Hammer K.A., Carson C.F., Riley T.V., 1999. Antimicrobial activity of essential oils and other plant extracts. J. Appl. Microbiol. 86, 985-990

Headon D.R., Walsh G., 1993. Yucca schidigera extracts and ammonia control. Livestock Environment IV. 4th International Symposium, University of Warwick, St. Joseph, Michigan, pp. 686-693

Hill G.M., Utley P.R., Newton G.L., 1987. Dietary urea influences on digestibility and utilization of diets containing peanut skins by steers. J. Anim. Sci. 64, 1-7

Hristov A.N., McAllister T.A., Van Herk F.H., Cheng K.-J., Newbold C.J., Cheeke P.R., 1999. Effect of Yucca schidigera on ruminal fermentation and nutrient digestion in heifers. J. Anim. Sci. 77, 2554-2563

Hussain I., Cheeke P.R., 1995. Effect of dietary Yucca schidigera extract on rumen and blood profiles of steers fed concentrate- or roughage-based diets. Anim. Feed Sci. Tech. 51, 231-242

Kil J.Y., Cho N.K., Kim B.S., Lee S.R., Maeng W.J., 1994. Effects of Yucca extract addition on the in vitro fermentation characteristics of feeds and feces, and on milk yields in lactating cows. Korean J. Anim. Sci. 36, 698-709

Klita P.T., Mathison G.W., Fenton T.W., Hardin R.T., 1996. Effects of alfalfa root saponins on digestive function in sheep. J. Anim. Sci. 74, 1144-1156

Kobeisy M.A., Boehm J., Buchner A., Leibetseder J., 2000. The effect of tannin on milk yield and some blood constituents in dairy cattle. Assiut Vet. Med. J. 43, 86-94

Kröber T.F., Külling D.R., Menzi H., Sutter F., Kreuzer M., 2000. Quantitative effects of feed protein reduction and methionine on nitrogen use by cows and nitrogen emission from slurry. J. Dairy Sci. 83, 2941-2951

Littell R.C., Henry P.R., Ammerman C.B., 1998. Statistical analysis or repeated measures data using SAS procedures. J. Anim. Sci. 76, 1216-1231

Makkar H.P.S., 1993. Antinutritional factors in foods for livestock. In: Animal Production in Developing Countries. Brit. Soc. Anim. Prod., Occasional Publications, 16, 69-85

McSweeney C.S., Palmer B., McNeill D.M., Krause D.O., 2001. Microbial interaction with tannins: nutritional consequences for ruminants. Anim. Feed Sci. Tech. 91, 83-93

Miner J.R., 1995. A review of the literature on the nature and control of odors from pork production facilities. http://www.mtcnet.net/ jdhogg/ozone/odor/odorlitreview.html 
Naumann K., Bassler R., 1997. Die chemische Untersuchung von Futtermitteln. Methodenbuch Vol. 3, VdLUFA-Verlag, Darmstadt (Germany)

Preston R.L., Bartle S.J., May T., Goposall S.R., 1987. Influence of sarsaponin on growth, feed and nitrogen utilization in growing male rats fed diets with added urea or protein. J. Anim. Sci. 65, 481-487

RAP (Station Fédérale de Recherches en Production Animale), 1999. Fütterungsempfehlungen und Nährwerttabellen für Wiederkäuer. 4th Edition. Landwirtschaftliche Lehrmittelzentrale, Zollikofen (Switzerland)

Śliwiński B.J., Soliva C.R., Machmüller A., Kreuzer M., 2002a. Efficacy of plant extracts rich in secondary constituents to modify rumen fermentation. Anim. Feed Sci. Tech. 101, 101-114

Śliwiński B.J., Kreuzer M., Wettstein H.-R., Machmüller A., 2002b. Rumen fermentation and nitrogen balance of lambs fed diets containing plant extracts rich in tannins and saponins, and associated emissions of nitrogen and methane. Arch. Anim. Nutr. 56, 379-392

Valdez F.R., Bush L.J., Goetsch A.L., Owens F.N., 1986. Effect of steroidal sapogenins on ruminal fermentation and on production of lactating dairy cows. J. Dairy Sci. 69, 1568-1575

Van Soest P.J., Conklin N.L., Horvath P.J., 1987. Tannins in foods and feeds. Proceedings of Cornell Nutrition Conference for Feed Manufactures, Ithaca, NY, Cornell University, Syracuse, NY, pp. $115-122$

Van Soest P.J., Robertson J.B., Lewis B.A., 1991. Methods for dietary fiber, neutral detergent fiber, and nonstarch polysaccharides in relation to animal nutrition. J. Dairy Sci. 74, 3583-3597

Villena F.J., Pfister J.A., 1990. Sand shinnery oak as forage for Angora and Spanish goats. http://jrm.library. arizona.edu/data/1990/432/7vill.pdf

Wallace R.J., McEwan N.R., McIntosh F.M., Teferedegne B., Newbold C.J., 2002. Natural products as manipulators of rumen fermentation. Asian-Austr. J. Anim. Sci. 15, 1458-1468

Wang Y., McAllister T.A., Cheeke P.R., Cheng K.-J., 1999. Assessment of inhibitory effects of ruminal fluid on biological activity of steroidal saponins using hemolytic assay. Can. J. Anim. Sci. 79, 561-564

West J.W., Hill G.M., Utley P.R., 1993. Peanut skins as a feed ingredient for lactating dairy cows. J. Dairy Sci. 76, 590-599

\section{STRESZCZENIE}

\section{Wyniki produkcyjne, konwersja azotu w organizmie i emisja azotu z odchodów krów mlecznych żywionych dawkami z dodatkiem różnych wyciągów roślinnych}

W dwóch doświadczeniach przeprowadzonych na krowach mlecznych badano wpływ dodatku małych ilości olejków eterycznych $(0,1 \mathrm{~g}$ wyciagu/kg; doświadczenie I), saponin z Yucca schidigera $(0,1 \mathrm{wyciagu} / \mathrm{kg})$ lub tanin z drzewa Castanea sativa $(4,9 \mathrm{~g}$ wyciagu $/ \mathrm{kg})$ porównując z dawką podstawową, nie uzupełnioną lub uzupełnioną śrutą sojową poekstrakcyjną (doświadczenie II). Na wyniki produkcyjne (zmiany m.c., wydajność i skład mleka) nie wpłynęły zastosowane dodatki, chociaż - celem wywołania efektu - były niedoborowe pod względem zawartości białka o $\leq 10 \%$. Wyjątek stanowiła dawka ze śrutą sojową, przy skarmianiu której stwierdzono tylko nieistotną tendencję zwiększenia wytrwałości laktacji i syntezy białka mleka. Wpływ dodatku wyciągów bogatych w saponiny i taniny uwidocznił się w poprawie wykorzystania azotu przez zwierzęta (mniej azotu mocznikowego w mleku i moczu) i zmniejszenie emisji azotu z odchodów po 8 tygodniach przechowywania. Głównym celem zastosowania wyciagów roślinnych bogatych w taniny i saponiny jest ograniczenie emisji azotu z odchodów zwierząt do środowiska. 